\title{
MAHMOUD MUHAMED TAHA: REDEFINISI KONSEP NASAKH SEBAGAI PEMBENTUK SYARIAT HUMANIS
}

\author{
Rasyidah Fathina \\ Fakultas Syari'ah UIN Maliki Malang \\ Telepon:085790815009 \\ Email: fatinq.1@gmail.com
}

\begin{abstract}
Abstrak
Islam adalah agama Rahmatan lil alamin dan Shalih likulli zaman wa makan. Islam yang dibutuhkan oleh umatnya adalah Islam yang lebih bersifat humanis untuk memecah hegemoni diantara umat Islam akibat permasalahan jenis kelamin, perbedaan agama dan sebagainya. Mahmoud Muhamed Taha

adalah salah satu tokoh intelektual muslim yang mengajukan gagasan untuk memberikan definisi ulang terhadap konsep nasakh sebagai salah satu upaya membentuk syariat yang lebih bersifat humanis sehingga Islam mampu menjadi agama yang Rahmatan lil 'alamin sebagaimana misi yang dibawa oleh Islam itu sendiri.
\end{abstract}

Islam is rahmatan lil alamin (blessing for the entire world) and shalil li kulli zaman wa makan ( can be implemented through time and space) religion. More humane Islam is needed by its adherents to break the hegemony among muslims due to gender, religion and some other problems. Mahmoud Muhamed Taha is one of prolific intellectual muslim who argues to redefine the concept of nasakh as the effort to build more humane syariat (Islamic Law) in order Islam is able to be Rahmatan lil 'alamin religion as it brings that mission.

Kata Kunci: Nasakh, Syariat, ayat Makkiyah, Ayat Madaniyyah

Tak dapat dipungkiri lagi bahwa perkembangan Islam di era klasik memang cukup signifikan dan berarti. Hal tersebut dapat dilihat dari kontribusi yang telah diberikan oleh Islam bagi segala lini kehidupan. Di bidang pemerintahan misalnya, Rasulullah secara tidak langsung telah mengajarkan mengenai konsep "otonomi daerah" dengan memberikan wewenang kepada gubernur untuk memimpin di tiap-tiap daerah dan bertanggung jawab langsung kepada Rasulullah. Perkembangan tersebut barlangsung sampai dengan tahun 1250 yang kemudian disusul dengan kemunduran Islam yang sangat drastis. Pada tahap selanjutnya, muncullah para pemikir-pemikir muslim modern yang berusaha untuk memperbaiki krisis metodologi yang cukup memprihatinkan berkenaan dengan upaya mengembalikan eksistensinya pada realitas sosial, politik, hukum dan budaya dalam tata pergaulan internasional. Hal ini berkaitan dengan situasi dunia modern yang sudah banyak berubah pasca persinggungan dunia muslim dengan dunia barat. Dalam hal ini, Timur Tengah adalah salah satu kawasan yang sangat subur dalam memproduksi pemikir muslim modern, sebagaimana ia juga merupakan kawasan yang makmur dalam melahirkan berbagai Islam (Revivalis, Haraki, Salafi, Wahabi di masa sekarang; Syi'i, Sunni, Khariji, Murji'i di masa lalu).

Secara umum, para pembaharu Arab di masa-masa awal kebangkitan meyakini bahwa Islam adalah agama yang cocok bagi setiap masa dan tempat (shalih li kulli zaman wa makan). Islam juga mampu beradaptasi dengan dunia modern, terma- 
suk dengan pencapaian ilmu pengetahuan dan dalam beberapa hal- nilai-nilai Barat. Jika terjadi konflik antara ajaran Islam dengan pencapaian modernitas, maka yang harus dilakukan, menurut mereka, bukanlah menolak modernitas, tetapi menafsirkan kembali ajaran tersebut.

Perkembangan pemikiran modern di dalam Islam, merupakan dinamisasi tersendiri dalam ruang keintelektualan yang tidak pernah habis dibahas karena perkembangan pemikiran ini adalah ruh kerisauan intelektual para pemikirpemikir Islam terdahulu, yang kemudian terwariskan pada generasi selanjutnya, seiring perkembangan zaman dan perjalanan waktu. Maka apabila berbicara tentang para tokoh-tokoh pemikir Islam kontemporer, akan terasa ganjil jika melupakan sosok Mahmoud Muhamed Taha, tokoh ini disinyalir termasuk tokoh pemikir yang langka dan memiliki dedikasi keilmuan sangat diperhitungkan dalam dunia pemikiran kontemporer. Akan tetapi Beliau adalah sosok aktifis yang memiliki loyalitas kerakyatan yang tinggi tampa mengurangi kekritisannya terhadap persoalan politik, hukum dan pemerintahan. Ini terbukti lewat afiliasi dalam lembaga HAM, meski demikian sosok Mahmoud Muhamed Taha juga adalah sosok akademis yang cemerlang.

Taha membedakan antara term Islam dan syariah. Menurutnya, Islam adalah sebuah ketundukan dan kepasrahan secara total dan meyakini Allah sebagai Tuhan. Adapun syariah bukanlah Islam itu sendiri melainkan hanyalah interpretasi terhadap teks/nash yang dipahami melalui konteks historis tertentu. Konsekuensi logis dari pemahaman tersebut adalah suatu kesalahan besar jika menerapkan syariah yang berlaku di abad ke tujuh ke abad ke dua puluh karena adanya perbedaan tingkat yang cukup tajam antara abad ke tujuh dan abad ke dua puluh.[1] Gagasan Taha taha ini yang selanjutnya akan dikupas lebih mendetail pada bab selanjutnya.

[1]Mahmoud Muhamed Taha, The Second Message Of Islam: Syariah Demokratik, terjemahan oleh Nur Rahman (Surabaya: eLSAD, 1996), 18-20.

\section{PEMBAHASAN Biografi}

Mahmoud Muhamed Taha adalah salah seorang pemikir modern Sudan yang dilahirkan pada tahun 1909 atau 1911 di Rufa'ah. Beliau dan saudarasaudaranya dibesarkan oleh kerabat jauhnya karena ibunya meninggal pada tahun 1915 sedangkan ayahnya pada tahun 1920. Taha adalah satusatunya anak yang dapat menyelesaikan pendidikan yang menggunakan sistem persaingan luar biasa yang diterapkan pada waktu itu. Beliau menyelesaikan pendidikan teknik pada Gordon Memorial College pada tahun 1936. Setelah menyelesaikan pendidikannya, beliau sempat bekerja sebagai seorang pegawai jawatan kereta api Sudan dan kemudian berhenti untuk mendirikan sebuah lembaga pendidikan sendiri pada awal tahun 1940an.[2]

Sejak awal timbulnya pergerakan pada akhir tahun 1930-an, Taha berparitispasi aktif dalam perjuangan kemerdekaan Sudan dari pemerintahan kolonial Anglo-Egyption. Namun kemudian ia tidak sependapat dengan pandangan elit terpelajar yang tergabung dalam pergerakan itu. Menurutnya kejelekan mereka adalah mengabdikan diri kepada pemimpin keagamaan tradisional yang sektarian. Partai-partai politik yang ada juga tidak dapat diterimanya, karena mereka cenderung akomodatif terhadap kolonial. Atas dasar itu Taha dan para intelektual lain yang sependapat membentuk Partai Republik (The Repubican Party) pada bulan Oktober tahun $1945 \mathrm{M}$.

Partai ini berorientasi Islam modernis, yang saat itu belum berkembang di Sudan. Kebijakan partai untuk konfrontasi secara terbuka dengan kekuasaan kolonial membawa para tokohnya pada akibat penangkapan dan penjatuhan hukuman terhadap Taha dan beberapa koleganya pada tahun $1946 \mathrm{M}$. Ia dipenjara selama satu tahun ketika menolak berhenti dari aktifitas politik yang menentang pemerintahan kolonial. Namun karena memuncaknya protes dari Partai Republik, maka Gubernur Genderal Inggris membebaskan Mahmoud setelah lima puluh hari dalam penjara. Pada tahun yang

[2]Mahmoud Muhamed Taha, The Second, 27. 
sama, ia memimpin demonstrasi besar-besaran memprotes kebijakan pemerintah dalam menangani pelanggaran pharaonik[3]. Taha tidak setuju terhadap sanksi kriminal dan cara penanganan yang dilakukan pemerintah terhadap pelaku tindak pidana tersebut. Ia sendiri, mendapat hukuman yang paling berat, yaitu dua tahun penjara. Selama menjalani hukuman kedua ini dan selanjutnya pengasingan diri (khalwah) di kota kelahirannya Rufa'ah, Taha menjalankan ibadah dengan penuh kesungguhan, sampai akhirnya mengalami pencerahan spiritual.

Kemudian dengan berakhirnya periode pengasingan diri pada Oktober $1951 \mathrm{M}$, ia memunculkan apa yang sebutnya sebagai Risalah Kedua Islam (Risalah Tsaniyah min alIslam). Setelah itu Taha mulai mensosialisasikan pemikirannya melalui berbagai ceramah, buku dan artikel dalam surat kabar. Sejak itu, awal tahun 1950-an, Partai Republik mengalami transformasi, dari partai politik, menjadi lebih berperan sebagai organisasi yang mendukung, mensosialisasikan dan mempublikasikan berbagai pemikiran Mahmûd.

Setelah Ja'far Numeiri menjadi presiden melalui kudeta militer pada tahun 1969 M, dan seluruh partai politik di Sudan dibubarkan Partai Republik berganti menjadi Persaudaraan Kaum Republik (Republican Brothers). Pada awal pemerintahan Numeiri ini, Taha masih rajin ceramah di tempat-tempat umum dan menuliskan berbagai pandangannya di surat kabar, sampai kemudian pada tahun 1973 M pemerintah melarangnya berceramah di depan publik. Kemudian pada tanggal 13 Mei 1983 M, sebelum program Islamisasi di canangkan oleh pemerintah, Taha dan sebagian pengikutnya ditahan tanpa pemeriksaan resmi, karena membuat selebaran yang mengkritik kebijakan-kebijakan pemerintah dalam menangani masalah yang merugikan nonmuslim. Selanjutnya, penahanan terhadap para anggota Republican Brothers terus berlangsung. Penahanan besar-besaran ini, menurut AnNa'im, dimotivasi untuk melancarkan program

[3]Pharaonik adalah tindak pidana penyunatan terhadap perempuan. penerapan syariah secara paksa di Sudan.[4] Sebagai respon terhadap protes internasional atas penahanan tersebut, atau hanya sebagai perangkap agar mereka dapat dikenakan sanksi undangundang Islam yang baru, semua kaum Republikan termasuk Taha dibebaskan pada tanggal 19 Desember 1984 M, setelah ditahan sekitar 19 bulan tanpa tuduhan. Ketika menyadari bahwa pembebasan itu hanya berdasarkan alasan yang kedua, Taha segera melakukan kampanye melawan kebijakan Islamisasi presiden Numeire.

Satu minggu setelah dibebaskan, Taha dan kaum Republikan menyebarkan selebaran tentang pencabutan undang-undang baru dan menuntut jaminan kebebasan sipil bagi seluruh rakyat Sudan secara demokratis. Menurut mereka, undangundang itu mendistorsi Islam, melecehkan manusia, dan membahayakan integrasi nasional. Karena selebaran itu, banyak kaum Republikan ditangkap. Taha sendiri ditangkap pada tanggal 5 Januari 1985 $\mathrm{M}$ atas tuduhan berusaha mengubah konstitusi, menghasut dan mendorong oposisi inkonstitusional terhadap pemerintah, mengganggu stabilitas umum, serta menjadi anggota organisasi terlarang. Proses pengadilan tersebut dilaksanakan pada tanggal 7 Januari dengan tuduhan yang dapat mengantarkan kelima tokoh tersebut ke pintu kematian. Akan tetapi prosesnya tertunda sehari karena kelima tokoh tersebut memboikot jalannya persidangan. Keputusan final dari persidangan tersebut adalah hukuman mati terhadap kelima tokoh tersebut,[5] bahkan di tingkat banding mereka dinyatakan telah kafir. Pada hari Jum'at tanggal 18 Januari 1985, Presiden Numeiri memimpin sendiri pelaksanaan hukuman gantung atas diri Taha.[6]

[4]Penafsiran Taha mengenai Islam mengantarkannya menjadi musuh sengit dari Ikhwanul muslimin sekutu kuat rezim dan merupakan kelompok agama yang mapan- dimana kelompok tersebut juga memiliki andil yang sangat besar terhadap penghidupan kembali hukuman murtad yang permah berlaku pada tahun 1968.

[5]Akan tetapi hukuman mati tersebut dapat dihapuskan asalkan mereka bersedia bertaubat dan menarik kembali statement mereka.

[6]Lihat: The Second Message Of Islam:Syariah 


\section{Kegelisahan Akademik}

Pada awalnya, kecenderungan Taha dipicu oleh semangat pemberontakan terhadap kolonialisme Eropa pada satu sisi, dan terhadap keterbelakangan kaum Muslim pada sisi lain. Oleh karena itu, misi Taha adalah pembebasan dari cengkeraman penjajahan dan pembebasan dari kebodohan. Dua misi ini terus berjalan secara beriringan. Pada dasarnya, Taha sendiri merupakan pemikir Islam sufi yang berusaha agar syariat Islam dapat dilaksanakan secara taat[7] serta syariah itu sendiri dapat dibumikan pada era modernism. Tokoh ini seringkali mengangkat persoalan-persoalan yang menurutnya dapat menyebabkan kemunduran Islam dan Negaranya. Ia menginginkan agar agama Islam dapat menjadi agama yang mempunyai responsibilitas terhadap perkembangan zaman dan agar negaranya dapat mengikuti persaingan dalam percaturan dunia. Pemikiran Taha berkembang di Negara Sudan yang saat itu juga masih menjadi jajahan Inggris. Pada masa hidupnya, diskriminasi terhadap wanita tampak begitu kental. Hal tersebut, menurutnya, tampak tidak hanya dalam kebijakan-kebijakan pemerintah, tetapi juga dalam pemahaman masyarakat Sudan terhadap ajaran Islam itu sendiri. Pada masa itu, jika seorang perempuan ikut berperan aktif dalam ranah publik maka akan terasa sangat asing sekali karena seorang perempuan hanya berperan dalam ranah domestik saja. Karakter yang paling mencolok dari partai republik adalah penghargaannya yang tinggi kepada perempuan yang semakin memainkan peranan yang nyata dalam aktivitasaktivitas gerakannya baik aktivitas internal maupuan aktivitas publiknya.[8]

Gerakan-gerakan oposisi yang dilakukan

Demokratik dalam kata pengantar yang diberikan oleh Abdullahi Ahmed An-Na'im.

[7]Mohamed Taha dkk., Pemikiran Islam: Dari Sayyid Ahmad Khan Hingga Nasr Hamid Abu Zayd, terjemahan oleh Wakhid Nur Efendi (Jakarta: Penerbit Erlangga, 2000), 110.

[8] Mohamed Taha dkk., Pemikiran, 105. oleh Taha dan kelompoknya mencapai puncaknya ketika rezim Numeiri melakukan Islamisasi, yaitu dengan cara memberlakukan syariah Islam (Islamic Law) sebagai hukum negara. Dalam hal ini, bukan berarti mereka tidak setuju dengan adanya pemberlakuan hukum Islam sebagai hukum negara, akan tetapi penolakan tersebut didasarkan pada asumsi bahwa pemberlakuan hukum Islam tersebut cenderung untuk memberi keuntungan secara politis pada kelanggengan rezimnya, bersifat sektarian, diskriminatif, intoleran dan bertentangan secara antagonis dengan standarisasi hak azazi manusia. Kebijakan Numeiri tentang pemberlakuan syariat Islam tentunya sangat bertentangan dengan pandangan yang telah lama ia dan partai Republik perjuangkan bahwa harus ada reformasi radikal hukum syariah lebih dulu bagi implementasi modern hukum syariah.

Di samping permasalahan tersebut, terkait dengan adanya gerakan Islam fundamental yang berkembang saat itu -ikhwanul muslimin- yang bahkan juga menjadi sekutu kuat rezim, Taha berusaha mengeluarkan gagasan-gagasan yang dapat mengantarkan umat manusia kepada kebebasan yang sebenarnya. Karena pada masa itu, gerakan tersebut juga telah banyak memberikan sumbangan pemikiran yang sangat ekstrim yang dirasa justru dapat menyudutkan Islam sendiri, seperti: adanya komando pelaksanaan jihad, penegakan syaria'at Islam, dan sebagainya. Pemikiran-pemikiran tersebutlah yang justru mengantarkan beliau menuju hukuman mati di tiang gantungan.

\section{Metode Penelitian Taha}

Dalam mengembangkan ide-idenya, Taha mengembangkan beberapa metode untuk memahami keberlakuan suatu ayat. Metode tersebut antara lain: Pertama, dengan menggabungkan antara spiritualitas dan rasionalitas. Berdasarkan pemaparan biografi di atas, diketahui bahwa konstruksi nalar Muhammad Taha dibentuk dari khazanah ilmu-ilmu tehnik, ilmu-ilmu sosial Barat, dan khazanah intelektual Islam khususnya tasawuf. Dengan membaca karya-karyanya kita akan mengetahui bahwa orientasi sufisme sangat kuat dalam pemikiran Taha. Hal ini disebabkan oleh karena beliau hidup di tengah masyarakat Sudan 
yang mempunyai kecenderungan Islam sufistis. Fungsi sufisme ini untuk meletakkan kembali dalam kehidupan keagamaan setiap muslim unsur penyatuan pribadi dengan Allah.[9]

Taha tidak banyak membicarakan laranganlarangan syariah yang meminggirkan bendabenda material, atau kekayaan tertentu yang ia pandang bersifat sementara. Kategori halal haram itu menurutnya dipandang sebagai sarana pendidikan di mana melalui hal itu manusia menuju kemajuan spiritualnya. Menurut Taha, maksud seorang individu pada pemurnian diri seharusnya mengikuti suatu metode di mana ia menyerukan kepada dirinya sendiri secara terus menerus untuk mempertanggungjawabkan dan mengakhiri dosanya pada tingkat perbuatan, lisan dan pemikiran. Catatan Taha dalam persoalan ini bersifat mekanistis yang pada umumnya menandakan perspektif psikologisnya. Begitu proses pemurnian diri ini selesai, lokus dari diri seseorang bergeser ke relung dalam. Orang akan melihat ke dalam dan tidak lagi tergoda pada hal fisik (eksternal). Ketika seseorang mencapai keadaan ini, di mana medan dalam sepenuhnya sesuai dengan prilakunya, maka syariah mengalami perubahan yang radikal, karena segenap substansi konkret yang diharamkan kembali pada keadaan awal yang halal.[10]

Kedua, adalah dengan menggunakan metode hermeneutik. Kata hermeneutik berasal dari bahasa Yunani, hermeneuin. Kata ini kerap diterjemahkan dengan to interpret (artinya: menginterpretasikan, menafsirkan dan menerjemahkan). Dalam studi keIslaman hermeneutik sudah lama dikenal dengan padanan kata tafsir, ta'wil, syarah dan bayan.[11] Mahmoud menggunakan metode hermeneutik ini pada bidang tafsir Al-Qur'an yang menurut beliau merupakan modernisasi dalam Islam.

Modernisasi Islam menurut Taha melibatkan

[9] Mahmoud Muhamed Taha, The Second, 36.

[10]Mohamed Taha dkk., Pemikiran, 111.

[11]Syahiron Syamsudin dkk., Hermeneutika AlQur'an Madzhab Yogya (Yogyakarta: Islamika, 2003), 54. suatu proses dialektika negasi (penyangkalan) dan afirmasi (peneriamaan) atas apa yang ditentukan oleh teks al-Qur'an. Metodenya adalah menegakkan kontak hermeneutika langsung dengan teks al-Qur'an. Oleh sebab itu, kecenderungan kaum modernis untuk menolak tradisi yang diterimanya mengambil bentuk yang ekstrim dalam pemikiran Taha, yang jarang mengacu pada warisan pasca alQur'an dan pasca rasul. Penyingkiran tradisi lainnya, yang diperoleh ini begitu kontras dengan pemasukan tradisi lainnya, yakni sains modern dan nilai-nilai sosial, politik dan ekonomi modem. Cakrawala al-Qur'an diperluas untuk bergabung ke dalam cakrawala epistemologis dan sosial dari masa modern.[12]

Salah satu permasalahan yang menggunakan pendekatan hermeneutik adalah permasalahan kedudukan wanita. Sebelum diturunkannya alQur'an, wanita sama sekali tidak memiliki nilai sama sekali di mata masyarakat waktu itu. Bahkan bayi-bayi wanita yang baru lahir akan segera dikubur hidup-hidup karena pada masa itu bayi wanita adalah salah satu bentuk aib terbesar. Oleh karena itu, pada saat diturunkannya ajaran Islam, maka sebagian besar masyarakatnya -baik laki-laki maupun perempuan - tidak dapat menerima begitu saja ajaran yang dibawanya. Masa transisional sangat dibutuhkan oleh laki-laki maupun perempuan sebagai individu, sebagaimana yang dibutuhkan oleh masyarakat untuk dapat berkembang secara utuh.

Yang menjadi catatan penting adalah bahwa meskipun Taha adalah seorang yang universalis, dan audiens dari seruan utamanya adalah umat manusia, penalarannya secara eksklusif berlandaskan secara kuat pada teks-teks Islam yang terbatas, yang sumber utamanya adalah al-Qur'an dan Hadis. Dia menerima sepenuhnya bahwa pembacanya adalah muslim dan otoritas mutlak alQur'an dan hadis tidak perlu diragukan.

Oleh karena itu, perdebatan tentang: Bagaimana seseorang bisa meraih "pemahaman yang benar" atas teks al-Qur'an dan hadis ini berkaitan dengan aspek utama pemikiran Taha lainnya, yakni ibadah. "Pemahaman yang benar" membawa pada "praktek yang benar" yang pada akhimya membu-

[12]Mohamed Taha dkk., Pemikiran, 123. 
ka pintu untuk tingkat "pemahaman yang benar" yang lebih tinggi dan terus melanjutkan proses yang tiada akhir.[13]

Ketiga, dengan menggunakan pembalikan nasakh atau redefinisi konsep nasakh. Teori nasakh yang dihasilkannya pada dasarnya juga melalui perjalanan spiritualnya yang cukup panjang. Ia banyak melakukan kegiatan-kegiatan spiritual berupa kontemplasi, puasa dan meditasi semata-mata dalam rangka mendapat setitik pencerahan dari Allah. Kegiatan spiritual yang dalam rangka mencarai inspirasi itulah yang kemudian oleh an-Naim disebut sebagai modern mystical approach.[14] Proses meditasi ini ternyata membawa dampak yang sangat efektif bagi diri Taha, hal itu terbukti dengan munculnya dua teori yang ia perkenalkan, yaitu teori mengenai shalat[15] yang bersandar pada konsep ashlah (otentisitas) dan teorinya mengenai risalah Islam yang kedua.[16]

Dalam Islam, pada dasarnya individulah yang menjadi pertaruhan syariah, sementara masyarakat mengikuti individu. Hal itu karena kesempurnaan individu hanya dapat berlangsung melalui pengalaman praksisnya dalam masyarakat sehingga seolah-olah beribadah dalam sunyi dan sendiri merupakan sekolah yang membekali individu dengan bekal teoretis, sedang ia tidak dapat menjadikannya praksis kecuali melalui aksi-aksi dalam masyarakat serta berinteraksi

[13]Mohamed Taha dkk., Pemikiran, 106.

[14]Imam Syaukani, Rekonstruksi Epistemologi

Hukum Islam Indonesia (Jakarta: PT. Raja

Grafindo Persada, 2006), 139.

[15]Terkait dengan kosepnya mengenai shalat, beliau mengatakan bahwa shalat-shalat yang ditetapkan dimaksudkan untuk membuat orangorang yang mendirikannya berada pada jalan yang mengikuti cara Rasul. Tindakan mengikuti secara sadar ini, pada akhirnya menyebabkan perwujudan kesatuan mistik dengan AllaPada titik seseorang menjadi otentik (ashlah) maka taklid pun akan berakhir. Lihat catatan kaki dalam, Mohamed Taha dkk., Pemikiran, 126.

[16]Imam Syaukani, Rekonstruksi, 105. secara intensif dengan individu-individu di dalamnya.[17]

Walaupun demikian, hasil perjalanan spiritualnya itu tetap mengantarkannya pada tiang gantungan karena pemikirannya dianggap dapat membahayakan akidah umat muslim. Ditambah lagi rezim yang berkuasa di Sudan saat itu merupakan sekutu dari kelompok konservatif, Ikhwanul muslimin, yang mereka dikenal gigih dalam memperjuangkan penegakan syari'at Islam. Konsep dasar mengenai risalah Islam kedua adalah didasarkan pada teori nasakh yang secara sepintas terdapat kesamaan dengan nasakh yang kita kenal dalam teori usul fiqih klasik tetapi sebenarnya sangatlah berbeda. Mengingat dalam teori ushul fiqh klasik, nasakh dimaksudkan dengan penghapusan hukum yang terdapat dalam ayat-ayat Makkiyah yang notabene turun lebih awal dengan ayat-ayat Madaniyah yang turun belakangan.[18] Sementara nasakh dalam pandangan Taha justru sebaliknya. Nasakh yang digagas oleh Taha adalah ayat makiyah lah yang harus menghapus ayat madaniyyah dengan alasan bahwa ayat-ayat makiyah bersifat lebih humanis, universal dan abadi karena menganjurkan kebebasan, persamaan derajat serta tidak adanya diskriminasi baik terkait dengan persoalan gender maupun agama dan kepercayaan. Metodologi yang ditawarkan oleh Taha adalah suatu upaya agar manusia mampu memperoleh kebebasan individu yang bertanggung jawab secara seutuhnya.

Persoalan lain yang membedakan antara nasakh dalam pandangan Taha dan ushul fiqh klasik adalah terkait dengan berlakunya hukum ayat yang telah dinasakh. Dalam ushul fiqh klasik, nasakh dipahami sebagai penghapusan yang berindikasi pada tidak berlakunya lagi kekuatan hukum suatu ayat karena datangnya ayat yang baru, sementara

[17]Mahmoud Muhamed Taha, Maknai Terus Shalatmu: Risalah Kebebasan Individu Dan Keadilan Sosial (Yogyakarta: LKiS, 2001), 100.

[18]Definisi di atas juga ditulis oleh Wahbah Zuhaili, menurutnya, Nasakh adalah menghapus hukum syara' yang turun lebih dulu (makkiyah) dengan dalil syara' yang turun belakangan (madaniyah). Lihat: Wahbah Zuhaili, al-Wajiz Fi Ushul Figh, (Damaskus: Darul Fikri, 2007) 237 
menurut Taha, nasakh tidak dapat dipahami sebagai penghapusan yang berarti ada ayat yang tidak lagi memiliki kekuatan hukum karena telah tergantikan oleh yang turun kemudian melainkan lebih tepatnya bila dipahami sebagai penundaan dalam hal aplikasinya.[19]

Menurutnya, ajaran Islam yang "orisinil" dan essensial terdapat dalam ayat-ayat Makkiyah, [20] tetapi karena kesadaran dan pola fikir bangsa Arab abad ke tujuh tidak bisa menerima dan memahami nilai-nilai universal Islam itu maka kemudian yang diturunkan dan diberlakukan adalah ayat-ayat Madaniyah yang hanya bersifat "tambahan". Bangsa Arab saat itu tidak bisa menerima apabila ada orang yang yakin dengan satu agama tetapi tetap menghormati agama lain, dan masih banyak contoh lain untuk menggambarkan rendahnya tingkat berfikir bangsa Arab abad ke tujuh.

Taha menyatakan bahwa bagian bacaan masa Makkah dan Madinah berbeda, bukan karena tempat dan waktu pewahyuannya, teteapi karena audiens yang disapanya.[21] Dalam menguraikan kasus ini Taha membalikkan perspektif evolusionernya dan juga meskipun bagian Makkah mendahului bagian Madinah, pesan-pesan Makkah justru menunjukkan "tingkat yang lebih tinggi", atau tingkat risalah yang kedua. Sehingga bagi Taha, tidak diaplikasikannya ayat-ayat makkiyah pada era kenabian disebabkan oleh kondisi khusus masyarakat Madinah dan Arabia pada waktu itu yang dekat dengan zaman Jahiliyah sehingga nabi sengaja tidak memperlakukan ayat-ayat makkiyah yang lebih humanis dan universal.[22]

Taha bermaksud untuk menunjukkan bahwa wahyu yang bersifat "tambahan" yang secara tradisional telah dianggap sebagai menyatu secara kekal dengan Islam dan terus berfungsi, kenyataanya tidak lagi relevan dan tidak dapat

[19]Imam Syaukani, Rekonstruksi, 141.

[20]Mohamed Taha dkk., Pemikiran, 116.

[21]Mahmoud Muhamed Taha, The Second Message, 110 .

[22]Imam Syaukani, Rekonstruksi, 141. memenuhi kebutuhan kaum muslim saat ini. Guna mendorong konsepnya ke arah Islam, dia menyibukkan dirinya dengan persoalan-persoalan spesifik seperti jihad, perbudakan, kapitalisme, ketidaksetaraan gender, poligami, perceraian, jilbab dan pemisahan jenis kelamin.[23] Dia menyatakan bahwa, meskipun semua ini merupakan aspek integral dari risalah pertama Islam, semua ini sebenarnya sudah tidak lagi sesuai dengan risalah kedua, yang asli.

Pernyataan Taha-sebagaimana yang dikutip oleh an-Naim dalam bukunya dekonstruksi syariah - adalah sebagai berikut:

Evolusi syariah seperti yang telah dijelaskan di atas adalah evolusi dengan perpidahan dari satu teks (al-Qur'an) ke teks yang lain, dari satu teks yang pantas untuk mengatur abad ke-7 dan telah diterapkan, pada suatu teks yang pada waktu itu terlalu maju dan oleh karena itu dibatalkan. Allah berfirman: "kapan saja Kami menasakh suatu ayat atau menundanya, Kami datangkan ayat yang lebih baik dari padanya atau ayat yang sepadan dengannya. Tahukan kamu bahwa Allah Maha Kuasa Atas segala sesuatu". Kalimat "Kami datangkan yang lebih baik" tadi berarti membatalkan atau mencabut, dan kalimat "atau menundanya" berarti menunda pelaksanaanya atau penerapannya. Kalimat "Kami datangkan ayat yang lebih baik dari padanya atau ayat yang sepadan dengannya." Berarti mendatangkan ayat yang lebih dekat dengan pemahaman masyarakat dan lebih sesuai dengan situasi mereka ketimbang ayat yang ditunda.

Dalam evolusi ini kami mempertimbangkan alasan di luar suatu teks. Jika ayat tambahan, yang digunakan sebagai penolak ayat utama yang digunakan pada abad ke-7 telah memfungsikan tujuannya secara sempurna dan menjadi tidak relevan lagi bagi era baru, kemudian ayat utama telah memungkinkan menghapuskannya dan ayat utama diberlakukan. Dengan cara ini, ayat utama kembali sebagai teks yang operatif pada abad ke-20 dan menjadi basis legislasi yang baru. Inilah yang di-

[23]Mahmoud Muhamed Taha, The Second Message, 192-206. 
maksud dengan evolusi syariah. Satu peralihan dari satu teks yang telah memfungsikan tujuannya dan digantikan dengan teks lain yang ditunda hingga waktunya tepat.[24]

Contoh kasus yang dikemukakan Taha adalah kasus nasakh terhadap ayat-ayat mengenai perintah jihad pada periode Madinah oleh ayatayat mengenai dakwah dengan damai dan toleransi terhadap orang non-Muslim. Maka seharusnya ayat-ayat perintah dakwah dengan damai dan toleran terhadap non-Muslim harus dibalik menghapus ayat-ayat yang terciptanya koeksistensi damai antara Muslim dan non-Muslim berdasar prinsip resiprositas.[25] Orang Muslim memperlakukan non-Muslim sebagaimana mereka memperlakukan Muslim. Sementara batasan tersebut diatur dalam hukum Internasional. Dari pembalikan naskh tersebut kemudian juga ingin diterapkan oleh Mahmoud terhadap ketentuan hukum mapan yang menimbulkan diskriminasi terhadap non-Muslim dan perempuan di depan hukum Islam.

Ketidaksamaan status konstitusional non-Muslim di bawah konstitusi yang berdasar kepada hukum Islam, harus diganti dengan tuntutan persamaan mutlak status kewarganegaraan non-Muslim bukan hanya sebagai warga negara kelas dua yang hak asasi kurang dijamin oleh konstitusi berdasarkan hukum Islam. Untuk itu revitalisasi konsep ummah yang meliputi seluruh warga negara tanpa membedakan ras agama dan gender. Konsep ummah kemudian dianggap sebagai konsep kolektif khilafah manusia di bumi dan wakil kedaulatan Tuhan. Aspek-aspek ayat-ayat Madaniah mendiskualifikasikan status konstitusional non-Muslim dan perempuan dalam kehidupan publik harus dihapuskan dengan

[24]Abdullahi Ahmed an-Naim, Dekonstruksi Syariah: Wacana Kebebasan Sipil, Hak Asasi Manusia Dan Hubungan Internasional Dalam Islam, (Yogyakarta: LkiS, 2004), 99-100

[25]Mahmoud Muhamed Taha, The Second Message, 192. pesan-pesan fundamental ayat-ayat Makiyyah yang menekankan persamaan dan solidaritas kemanusiaan di bawah konstitusi Islam.

Di samping itu, ayat-ayat madaniyah yang dimaksud oleh Taha sebagai ayat yang penuh diskriminasi misalnya ayat yang berbicara tentang kesaksian dua perempuan yang dianggap sama dengan kesaksian satu orang laki-laki, begitu juga halnya dalam hal pembagian harta warisan dengan bagian setengah dari bagian laki-laki, maupun ayat yang mewajibkan jizyah bagi non muslim.[26] Ayat-ayat semacam inilah yang tidak relevan lagi untuk diterapkan dalam konteks kekinian dan harus digantikan oleh ayat-ayat makkiyah yang sifatnya lebih humanis dan universal serta menghapus segala bentuk diskrimiasi.

Dalam hal ini ia mengajukan argumen sebagai berikut: Pertama; Al-Qur'an merupakan wahyu terkhir dan Nabi Muhammad merupakan Nabi yang terakhir juga. Konsekuensinya, alQuran harus berisi semua yang dikehendaki Allah untuk diajarkan, baik ajaran yang akan diterapkan segera maupun ajaran yang akan diterapkan pada waktu yang akan datang. Kedua; Demi martabat dan kebebasan yang dilimpahkan Allah kepada seluruh umat manusia, Allah menghendaki umat manusia belajar melalui pengalaman praktis mereka sendiri dengan tidak bisa diterapkannya pesan Mekkah yang lebih awal yang kemudian ditunda dan digantikan oleh pesan Madinah yang lebih praktis.

Abdullahi Ahmed An-Na'im, salah seorang murid Taha, sangat menyetujui gagasan yang dikeluarkan oleh Taha dengan beberapa alasan: Pertama, pesan Makkiyah adalah pesan abadi dan fundamental yang menginginkan egalitarianisme seluruh Ummat manusia. Akan tetapi, karena pesan Makkyah ini belum siap diterapkan pada masyarakat abad ke $7 \mathrm{M}$, Tuhan menurunkan pesan Madaniyah yang lebih sesuai dengan kondisi zaman pada waktu itu. Kedua, aspek pesan Makkiyah adalah abadi, hanya karena alasan kondisi zaman, pesan yang abadi itu ditunda pelaksanaannya. Ketiga, pemberlakuan teori nasakh itu tidak permanen. Sebab jika permanen maka umat Islam menolak sebagian dari

[26]Imam Syaukani, Rekonstruksi, 142. 
Agamanya.

Dengan pembalikan proses nasakh, menurut Taha pembangunan hukum Islam humanis sebagai sistem hukum yang koheren secara internal dan konsisten dapat terpenuhi, sehingga masyarakat Muslim tidak perlu menempuh jalur konservatif dengan mempermudah hukum Islam yang sudah ada sehingga menimbulkan problem serius, karena tidak memadainya hukum Islam diterapkan pada masyarakat Muslim kontermporer. Juga Muslim tidak perlu menempuh jalur sekularisme hukum, sehingga dapat dilaksanakan sebagai bagian dari tugas keagamaan dan sosial masyarakat Muslim, tanpa mengorbankan kelompok masyarakat lain sesuai dengan asas resiprositas atau timbal balik.

\section{KESIMPULAN}

Taha memperkenalkan sebuah teori pembalikan nasakh dalam pendekatannya terhadap

\section{DAFTAR PUSTAKA}

An-Naim, Abdullahi Ahmed. 2004. Dekonstruksi Syariah: Wacana Kebebasan Sipil, Hak Asasi Manusia Dan Hubungan Internasional Dalam Islam. Yogyakarta: LkiS.

Ebigebriel, Maftuh dan Ibida Syitaba. 2004. Fundamentalisme Islam: Akar Teologis dan Politis dalam Negara Tuhan: The Thematic Encyclopaedia.

Yogyakarta: SR- Ins Publising.

Mahmoud, Mohamed dkk. 2000. Pemikiran Islam: Dari Sayyid Ah- syariah. Menurut Taha masyarakat Islam modem harus memegang teguh ayat-ayat Al-Qur'an yang sesuai dengan kondisi masyarakat modern. Ayatayat tersebut adalah ayat-ayat Makkiyah yang memiliki standar lebih tinggi dari pada ayat-ayat Madaniyah. Ayat-ayat Makkiyah mengandung nilai humanis, universal dan abadi karena menganjurkan kebebasan, persamaan derajat serta tidak adanya diskriminasi baik terkait dengan persoalan gender maupun agama dan kepercayaan. Akan tetapi hal tersebut bukan berarti membuang dan tidak menerima adanya ayat-ayat Madaniyah karena konsep nasakh yang dimaksud oleh Taha bukanlah menghapus, akan tetapi lebih bersifat penundaan dalam hal pelaksanaannya sampai dengan adanya kesiapan dari masyarakat muslim untuk menerapkan ayat-ayat yang memiliki standar lebih tinggi tersebut

mad Khan Hingga Nasr Hamid Abu Zayd. Terjemahan oleh: Wakhid Nur Efendi. Jakarta: Penerbit Erlangga

Syamsudin, Syahiron dkk., 2003. Hermeneutika Al-Qur'an Madzhab Yogya. Yogyakarta: Islamika

Syaukani, Imam. 2006. Rekonstruksi Epistemologi Hukum Islam Indonesia. Jakarta: PT. Raja Grafindo Persada

Taha, Mahmoud Muhamed. 1996. The Second Message Of Islam: Syari'ah Demokratik. Terjemahan oleh: Nur Rahman. Surabaya: Elsad 2001. Maknai Terus Shalatmu: Risalah Kebebasan Individu Dan Keadi- 